\title{
CONCRETE WASTE AUDIT METHODOLOGY FOR HOUSING PROJECTS IN INDIA
}

\author{
Sameersinh Alone ${ }^{1}$, Priyadarshi Sawant ${ }^{2}$ \\ ${ }^{1}$ Research Scholar, Sardar Patel College of Engineering, Andheri (W), Mumbai-58, India \\ ${ }^{2}$ Professor and Principal, Sardar Patel College of Engineering, Andheri (W), Mumbai-58, India
}

\begin{abstract}
Minimising construction waste is a challenge for building construction industry. Very little study is carried out to audit construction waste. In absence which construction practitioners find it difficult to design most apt waste minimization \& management tool. In this study, an attempt is made to develop a methodology to audit concrete waste from housing projects in India by deriving concrete waste indices. This paper is based on survey of 51 buildings from Maharashtra, India. 50 concrete waste generating factors (CWGF) were identified and grouped in five categories. Level of influence and factor weightages were identified from filed observations and questionnaire survey, and respondents' rating on four point Likert scale was measured to find waste audit scores. This data is used to find Concrete Waste Index. Model was developed for auditing concrete waste.
\end{abstract}

Model presented is easy to use for practitioners to find concrete waste on their sites. There is an established set of influencing factors which help them prepare best waste management system on site. Performance of concreting activity can be measured using this tool. Project owners can use it to measure loss in profit due to excess waste than standard. Results can be used by contractors and project managers to benchmark concrete waste and design waste minimization plan to have better control on concrete waste.

Keywords: Concrete Waste, material waste, waste audit, construction waste management. $* * *$

\section{INTRODUCTION}

Waste, in general, has been conceptualized as just a physical construction waste rather than more generic conception of the term that includes both the incidences of loss of resources and energy leading to execution of unnecessary work. It generates additional cost to the product but does not add any value to it [1]. It calls for extra efforts to manage it further. On construction sites, waste of material is very commonly observed in India. It occurs at any project stage at planning, designing, procurement, transport, handling and execution [8].Skoyles viewed this waste as a loss of project profit [14]. Impact of such losses is to be understood deeply that adversely influence sustainability of the environment. It negatively affects the project performance causing delay and cost overruns. It is to be understood that wastage can't be completely avoidable. Teoet. al. report that the least and the highest percentage contribution of material wastage to cost overrun between $21-30 \%$ and $31-40 \%$ respectively [3]. Bossink and Bornwers who observed that 20-30\% of building material purchased ended up as waste on site which can be viewed as their percentage contribution to project cost overrun [2]. The literature review reveals that, there is a high range of cost overrun arising from wastages of martial on site [6]. The study conducted by Ruben and Theo concluded that variation orders on construction projects contribute to cost $\&$ time overruns leading to significant loss in productivity by $9 \%$ and $33 \%$ respectively. Predominant cause identified was changes in the design [4].
Indian construction industry lacks in identification of waste sources. Awareness, design and application of waste management are lacking in the absence of government regulations [7]. Real estate industry in India is been led by contractors and builders who are non-technical in majority! This could be one of the reasons why Indian construction industry lacks in establishing control systems for waste. [12] It is estimated that the construction industry in India generates about 10-12 million tons of waste annually which is a significant reason to work in this area to reduce it [9]. Management of waste is a key to achieve sustainable development. Large companies have started using techniques like lean construction, precast manufacturing etc. to minimization wastage and improve processes; while most of the companies are yet to address this issue [5]. It's high time that practitioners and construction managers of Indian real estate construction industry have to accept the challenge to make constructions more sustainable by reducing waste in it. For this, correct identification of sources of waste generation and its assessment is important. As compared to other developing / developed countries, very less research is carried out in India focusing on this issue [12].

Literature review leveled that concrete waste varies from $1 \%$ to $15 \%$ of the total material quantity, while universal benchmark for structural concrete waste is $2[10,11,13]$. Results of major studies are summarized in Table 1. 
Table 1: Concrete waste as percentage of total material

\begin{tabular}{|l|l|l|l|l|l|l|}
\hline $\begin{array}{l}\text { Pint } \\
\text { o } \\
(198 \\
9)\end{array}$ & $\begin{array}{l}\text { Soibel } \\
\text { man } \\
(1994)\end{array}$ & $\begin{array}{l}\text { Pinto } \\
\text { and } \\
\text { Agopa } \\
\text { yan } \\
(1994)\end{array}$ & $\begin{array}{l}\text { Poo } \\
\text { n } \\
(200 \\
1)\end{array}$ & $\begin{array}{l}\text { Gara } \\
\text { s } \\
(200 \\
1)\end{array}$ & $\begin{array}{l}\text { Shen } \\
(200\end{array}$ & $\begin{array}{l}\text { Josephs } \\
\text { on and } \\
\text { Saukkor } \\
\text { iipi } \\
(2007)\end{array}$ \\
\hline $\begin{array}{l}\text { Braz } \\
\text { il }\end{array}$ & Brazil & Brazil & $\begin{array}{l}\text { Hon } \\
\text { Kon } \\
\text { Kon } \\
\mathrm{g}\end{array}$ & $\begin{array}{l}\text { Egy } \\
\text { pt }\end{array}$ & $\begin{array}{l}\text { Hon } \\
\text { Kon } \\
\text { Kon } \\
\text { g }\end{array}$ & Sweden \\
\hline $1 \%$ & $12 \%$ & $2 \%$ & $\begin{array}{l}3- \\
5 \%\end{array}$ & $4 \%$ & $\begin{array}{l}3.5- \\
6 \%\end{array}$ & $15 \%$ \\
\hline
\end{tabular}

Concern on the waste management is increasing day by day and in absence of robust waste audit method, Indian real estate sector is suffering from major losses of material and profit. It is therefore important to quantitatively assess the waste parameters and define their priority to design waste management system. Objective of this paper is to develop robust yet simple to use audit methodology for practitioners to assess level of waste. The model proposed contains 47 established set of influencing factors which help them identify, prioritize and prepare better waste management system. Performance of concreting activity can be measured using this tool. Project owners can use it to measure loss in profit due to excess waste than standard. Researchers can use this tool to design audit methodologies for other construction items.

Study in this paper is based on survey of 51 building sites. Fifty top ranked factors influencing generation of concrete waste on site were identified. These were grouped in five major categories depending upon their source of generation. Four point Likert scale was used to find waste audit scores and Concrete Waste Index for each of the projects under study were generated using 4 various parameters. SPSS statistic 12 software was used for regression analysis and model was developed for auditing concrete waste.

\section{METHODOLOGY}

For the purpose of this study, Concrete Waste Influence Factor (CWIF) is defined as "a factor that has potential to cause concrete waste in prevailing site conditions." Overall method was divided into four stages. In stage one, concrete waste generating factors (CWGF) were identified, scrutinized and categorized. In second stage, factors required to find waste index of category were identified and in stage 3 waste index of major category was calculated. Regression was carried out to standardize the values of waste parameter was done in stage 4 .

\subsection{Identification of Concrete Waste Generating}

\section{Factors - CWGF}

Various factors influence generation of concrete waste on site were identified. Data was analyzed to select most common and important CWG factors. Top ranked 50 were selected as relatively more influencing factors for this study. These were grouped in five major categories depending upon their source of generation viz. (A) 9 in Design, Specifications and Contract, (B) 14 in Materials, Machinery and Equipment, (C) 6 in Manpower, (D) 16 in Project Management, Planning and Methodology. 5 factors were considered to be uncontrollable and defined as (E) category. More than 53 practitioners were approached with questionnaire and 26 responses were considered to be valid. On the basis of average mean value of all 26 responses. Weightages of factors falling out of range of (mean value \pm $\mathrm{SD})$ were discarded from the sample to maintain the high accuracy. These factors were coded as A1, A2,.. B1, B2,.. etc. to maintain uniqueness. They are tabulated as shown in Table 2.

Table 2: Category wise construction waste influencing factors

\begin{tabular}{|c|c|c|c|}
\hline $\begin{array}{l}\text { Cate- } \\
\text { gory }\end{array}$ & CWGF & $\begin{array}{l}\text { Cate- } \\
\text { gory }\end{array}$ & CWGF \\
\hline $\mathrm{A}$ & \multicolumn{3}{|c|}{ Design, Specifications and Contract } \\
\hline A1 & $\begin{array}{l}\text { Inappropriate } \\
\text { designs issued by } \\
\text { Architects and } \\
\text { consultants } \\
\text { leading to wrong } \\
\text { executions causing } \\
\text { rework / waste }\end{array}$ & A6 & $\begin{array}{l}\text { Incomplete } \\
\text { Estimate, BOQ } \\
\text { leading to } \\
\text { misunderstanding } \\
\text { and errors in } \\
\text { concrete casting }\end{array}$ \\
\hline $\mathrm{A} 2$ & $\begin{array}{l}\text { Excess safety } \\
\text { margin than } \\
\text { needed leading to } \\
\text { higher cost - } \\
\text { waste of money }\end{array}$ & A7 & $\begin{array}{l}\text { Height of building } \\
\text { (Greater height } \\
\text { leading to more } \\
\text { waste) leading to } \\
\text { increasing } \\
\text { distance of } \\
\text { concrete handling } \\
\text { and placing }\end{array}$ \\
\hline A3 & $\begin{array}{lr}\text { Complexity } & \text { of } \\
\text { detailing, heavy } & \text { work, } \\
\text { RCC } & \\
\text { ornamental and } \\
\text { uneconomical } \\
\text { shapes } \\
\text { concreting items, } \\
\text { deviation } \\
\text { dimensions } \\
\text { leading in } \\
\text { efforts, specialized } \\
\text { concreting job, } \\
\text { spillage and waste }\end{array}$ & A8 & $\begin{array}{l}\text { Excessive } \\
\text { reinforcement, } \\
\text { conducting and } \\
\text { concealed piping } \\
\text { leading ro } \\
\text { segregation and } \\
\text { bad quality work } \\
\text { needing rework / } \\
\text { patchwork }\end{array}$ \\
\hline A4 & $\begin{array}{l}\text { Changes in design, } \\
\text { material, and } \\
\text { method after start } \\
\text { of work }\end{array}$ & A9 & $\begin{array}{l}\text { Changes by end } \\
\text { user causing } \\
\text { change in design } \\
\text { etc. after start of } \\
\text { execution }\end{array}$ \\
\hline A5 & $\begin{array}{l}\text { Unclear } \\
\text { instructions } \\
\text { specifications } \\
\text { information } \\
\text { leading to wrong / } \\
\text { arbitrary } \\
\text { assumptions and } \\
\text { hence mistakes in }\end{array}$ & & \\
\hline
\end{tabular}




\begin{tabular}{|c|c|c|c|}
\hline & $\begin{array}{l}\text { ordering materials, } \\
\text { executing } \\
\text { specifications, use } \\
\text { of machineries etc. }\end{array}$ & & \\
\hline B & \multicolumn{3}{|c|}{ Materials, Machinery and Equipment } \\
\hline B1 & $\begin{array}{lr}\text { Poor } & \\
\text { housekeeping, bad } \\
\text { storing } & \text { and } \\
\text { handling } & \text { of } \\
\text { materials } & \\
\end{array}$ & B8 & $\begin{array}{l}\text { Bursting of } \\
\text { concrete pipe, loss } \\
\text { in pumping, } \\
\text { handling } \\
\text { concrete on site }\end{array}$ \\
\hline B2 & $\begin{array}{l}\text { Non availability / } \\
\text { interrupted supply } \\
\text { of material, water, } \\
\text { power, fuel and } \\
\text { delays thereof }\end{array}$ & B9 & $\begin{array}{l}\text { Chocking of pipes } \\
\text { because of } \\
\text { unworkable } \\
\text { concrete }\end{array}$ \\
\hline B3 & $\begin{array}{l}\text { Use of unsuitable / } \\
\text { non matching } \\
\text { plant, equipment } \\
\text { and machineries }\end{array}$ & B10 & $\begin{array}{lr}\text { Faulty } & \text { formwork } \\
\text { and } & \text { scaffold } \\
\text { leading } & \text { to } \\
\text { breaking } & \text { and } \\
\text { leakage, } & \text { rework } \\
\text { etc. } & \\
\end{array}$ \\
\hline B4 & $\begin{array}{lr}\text { Poor } & \text { and } \\
\text { unplanned } & \\
\text { maintenance } & \text { of } \\
\text { equipment } & \text { and } \\
\text { RMC } & \text { plant } \\
\text { leading } & \text { to } \\
\text { malfunctioning } \\
\text { and } \\
\text { performance } & \\
\end{array}$ & B11 & $\begin{array}{l}\text { Use of cast-in-situ } \\
\text { concrete instead } \\
\text { of RMC causing } \\
\text { more waste in } \\
\text { handling, mixing, } \\
\text { pouring etc. }\end{array}$ \\
\hline B5 & $\begin{array}{l}\text { Underutilization } \\
\text { of plant and } \\
\text { machineries } \\
\text { leading to delays } \\
\text { causing fatigue, } \\
\text { extended work } \\
\text { hours and bad } \\
\text { quality concreting }\end{array}$ & B12 & $\begin{array}{l}\text { Excessive reuse of } \\
\text { shuttering }\end{array}$ \\
\hline B6 & $\begin{array}{l}\text { Error in } \\
\text { procurement } \\
\text { ordering, wrong } \\
\text { requisitions } \\
\text { leading } \\
\text { over/under } \\
\text { production, wrong } \\
\text { deliveries etc. } \\
\end{array}$ & B13 & $\begin{array}{l}\text { Rejection of } \\
\text { concrete load on } \\
\text { account of faulty } \\
\text { delivery }\end{array}$ \\
\hline B7 & $\begin{array}{l}\text { Waste in last pour } \\
\text { in case of casting } \\
\text { using pumping }\end{array}$ & B14 & $\begin{array}{lr}\text { Shortage } & \text { of } \\
\text { centering } & \text { and } \\
\text { shuttering } & \\
\text { material } & \\
\end{array}$ \\
\hline $\mathrm{C}$ & Manpower & & \\
\hline $\mathrm{C} 1$ & $\begin{array}{l}\text { Human errors in } \\
\text { interpretation } \\
\text { information }\end{array}$ & $\mathrm{C} 4$ & $\begin{array}{l}\text { Unskilled } \\
\text { workforce }\end{array}$ \\
\hline $\mathrm{C} 2$ & $\begin{array}{l}\text { Substandard } \\
\text { performance by } \\
\text { RCC contractor } \\
\text { and his team } \\
\text { inability } \\
\text { penalize }\end{array}$ & $\mathrm{C} 5$ & $\begin{array}{l}\text { Careless } \\
\text { workmanship, } \\
\text { Mistakes and } \\
\text { errors }\end{array}$ \\
\hline
\end{tabular}

\begin{tabular}{|c|c|c|c|}
\hline & $\begin{array}{ll}\text { contractor } & \text { in } \\
\text { absence } & \text { of } \\
\text { agreement } & \text { or } \\
\text { wrong agreement }\end{array}$ & & \\
\hline $\mathrm{C} 3$ & $\begin{array}{l}\text { Insufficient labor } \\
\text { force }\end{array}$ & C6 & $\begin{array}{l}\text { Substitution by } \\
\text { unskilled worker } \\
\text { to achieve } \\
\text { deadline leading } \\
\text { to inferior quality } \\
\text { of work / use of } \\
\text { faulty system etc. } \\
\text { causing waste }\end{array}$ \\
\hline $\mathrm{D}$ & \multicolumn{3}{|c|}{ Project Management, Planning and Methodology } \\
\hline D1 & $\begin{array}{l}\text { Unsupervised } \\
\text { work of } \\
\text { subcontractor, lack } \\
\text { of checking and } \\
\text { inspection leading } \\
\text { to bad quality of } \\
\text { work leading to } \\
\text { waste }\end{array}$ & D9 & $\begin{array}{l}\text { Bad sequencing of } \\
\text { operations, } \\
\text { selection } \\
\text { inappropriate } \\
\text { method of } \\
\text { handling / pouring } \\
\text { of concrete }\end{array}$ \\
\hline D2 & $\begin{array}{l}\text { Lack of liaison } \\
\text { between design } \\
\text { and construction } \\
\text { teams }\end{array}$ & D10 & $\begin{array}{l}\text { Approvals (from } \\
\text { local bodies, } \\
\text { consultants, } \\
\text { management ) not } \\
\text { received before } \\
\text { start of work } \\
\text { causing changes } \\
\text { and rework }\end{array}$ \\
\hline D3 & $\begin{array}{l}\text { Noninvolvement } \\
\text { of concerned } \\
\text { stakeholders in } \\
\text { decision making } \\
\text { leading to } \\
\text { unnecessary } \\
\text { revisions and } \\
\text { eleventh hour } \\
\text { changes leading to } \\
\text { rework }\end{array}$ & D11 & $\begin{array}{l}\text { Absence of } \\
\text { wastage control } \\
\text { team/system/plan }\end{array}$ \\
\hline D4 & $\begin{array}{lr}\text { Bad layouts, } \\
\text { accesses and site } \\
\text { plans } & \text { and } \\
\text { positioning of } \\
\text { machineries, lifts, } \\
\text { cranes etc. }\end{array}$ & D12 & $\begin{array}{lr}\text { Poor cash flow } \\
\text { forcing } \\
\text { substitutes to } \\
\text { substandard items }\end{array}$ \\
\hline D5 & $\begin{array}{l}\text { Wrong sampling } \\
\text { techniques / no } \\
\text { testing of concrete } \\
\text { leading to rework }\end{array}$ & D13 & $\begin{array}{l}\text { Bad working } \\
\text { conditions on } \\
\text { account of bad } \\
\text { site layouts, } \\
\text { untidy site, } \\
\text { insufficient work } \\
\text { space, unsafe site } \\
\text { leading to more } \\
\text { waste }\end{array}$ \\
\hline D6 & $\begin{array}{l}\text { Unbalanced team } \\
\text { and gangs leading } \\
\text { to substandard } \\
\text { performance }\end{array}$ & D14 & $\begin{array}{l}\text { Lack of support } \\
\text { from higher } \\
\text { management to } \\
\text { implement } \\
\text { wastage control }\end{array}$ \\
\hline
\end{tabular}




\begin{tabular}{|c|c|c|c|}
\hline D7 & $\begin{array}{l}\text { Lack of incentive } \\
\text { to control and } \\
\text { reduce concrete } \\
\text { waste and quality } \\
\text { performance }\end{array}$ & D15 & $\begin{array}{l}\text { Lack of flexibility } \\
\text { in planning and } \\
\text { execution, } \\
\text { implementation of } \\
\text { new ideas to } \\
\text { reduce waste }\end{array}$ \\
\hline D8 & $\begin{array}{l}\text { Lack of / poor } \\
\text { planning of } \\
\text { concreting activity }\end{array}$ & D16 & $\begin{array}{l}\text { Excessive } \\
\text { subcontracting or } \\
\text { departmental } \\
\text { work }\end{array}$ \\
\hline $\mathrm{E}$ & \multicolumn{3}{|c|}{ Other (Uncontrollable) } \\
\hline E1 & $\begin{array}{l}\text { Interference of } \\
\text { local authorities } \\
\text { on various issues } \\
\text { leading to waste }\end{array}$ & E4 & $\begin{array}{l}\text { Rainfall, } \\
\text { breakdown in law } \\
\text { and order, change } \\
\text { in rule etc. } \\
\text { requiring rework }\end{array}$ \\
\hline E2 & $\begin{array}{l}\text { Seasonal } \\
\text { fluctuation and } \\
\text { lack of skilled } \\
\text { workers }\end{array}$ & E5 & $\begin{array}{l}\text { Theft } \\
\text { vandalism }\end{array}$ \\
\hline E3 & $\begin{array}{ll}\begin{array}{l}\text { Accidents } \\
\text { mishaps }\end{array} & \text { and } \\
\end{array}$ & & \\
\hline
\end{tabular}

\subsection{Identification of Parameters to find Waste}

\section{Index of Category}

Three main parameters of waste were identified by researchers viz. waste influencing level, weightage of factor within category of waste, and audit score. To assess importance of waste parameters, an assessment tool was prepared using excel sheet. Respondents were then requested to rank these factors as the scale of 1 to 50 based on their influence power to cause concrete waste. They were then told to judge the potential influence (influence level) of these factors, on the scale of 1 to 10. Considering total weightage as 10 , each factor was judged by them on the basis of its importance to cause concrete waste in the respective category. This value was considered as 'weightage'. Response questionnaire in the form of scorecard was circulated. In order to measure the degree of agreement on the finalized factors quantitatively, each factor was converted into a "question-response" format. Responses were judged on 4 point Likert scale - (i) Yes, always or Strongly agree- with score value of 1 ; (ii) Yes, but moderately or Somewhat agree- with score value of 0.66 ; (iii) Yes, but rarely or Somewhat disagree - with score value of 0.33 and (iv) No / Disagree- with score value of 0. It is represented in Table 3.

Table 3: Audit score card- partial survey result for factors $\mathrm{C} 1$ and $\mathrm{C} 2$

\begin{tabular}{|c|c|c|c|c|}
\hline $\begin{array}{l}\text { Fac } \\
\text { tor } \\
\text { Co } \\
\text { de }\end{array}$ & Influence factor & $\begin{array}{l}\text { Response } \\
\text { Options }\end{array}$ & $\begin{array}{l}\text { Score } \\
\text { value }\end{array}$ & $\begin{array}{l}\text { Audit } \\
\text { Score } \\
\text { of } \\
\text { respon- } \\
\text { dent }\end{array}$ \\
\hline $\mathrm{C} 1$ & $\begin{array}{lr}\text { Is concrete } & \text { waste } \\
\text { takes place } \\
\text { because of } \\
\text { human errors in } \\
\end{array}$ & $\begin{array}{l}\text { a) Yes, } \\
\text { always. } \\
\text { b) Yes, but } \\
\text { moderately. }\end{array}$ & 0.66 & 0 \\
\hline
\end{tabular}

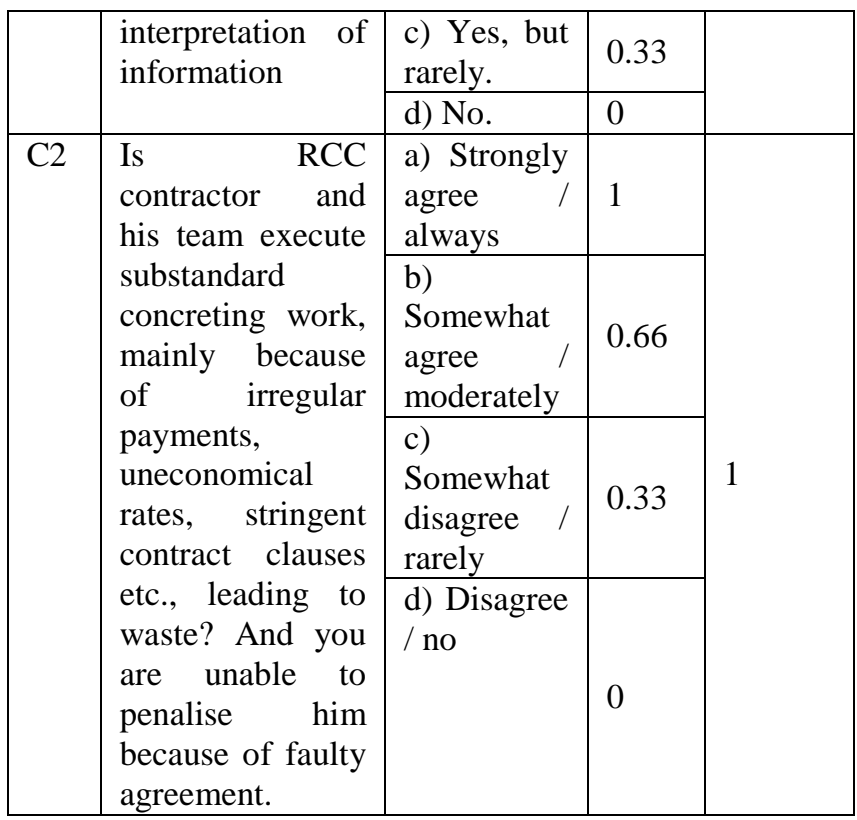

As seen in Table 4, rating for each CWGF and that of category of concrete waste were calculated from influence level, factor weightage and audit score. Factor rating was calculated by multiplying influence level, factor weightage and audit score. While category rating was simply the sum of all factor ratings within a category.

Table 4: Generation of factor rating \& Category rating

\begin{tabular}{|c|c|c|c|c|c|}
\hline $\begin{array}{l}\text { Facto } \\
\mathrm{r} \\
\text { Code }\end{array}$ & $\begin{array}{l}\text { Influen } \\
\text { ce } \\
\text { level } \\
\text { (a) }\end{array}$ & $\begin{array}{l}\text { Factor } \\
\text { Weightage } \\
\text { (b) }\end{array}$ & $\begin{array}{l}\text { Audit } \\
\text { Score } \\
\text { (c) }\end{array}$ & $\begin{array}{l}\text { Facto } \\
\mathrm{r} \\
\text { rating }\end{array}$ & $\begin{array}{l}\text { Categ } \\
\text { ory } \\
\text { rating }\end{array}$ \\
\hline $\mathrm{C}$ & $\begin{array}{l}(0) \text { to } \\
10)\end{array}$ & $\begin{array}{l}\text { (Total sum } \\
1 \text { within all } \\
\text { factors) }\end{array}$ & $\begin{array}{l}\text { (4 point } \\
\text { Likert } \\
\text { scale) }\end{array}$ & $\begin{array}{l}\mathrm{d}= \\
\mathrm{a}^{*} \mathrm{~b} * \mathrm{c}\end{array}$ & $\Sigma \mathrm{d}$ \\
\hline $\mathrm{C} 1$ & 7 & 1 & 0 & 0.00 & \multirow{6}{*}{64.24} \\
\hline $\mathrm{C} 2$ & 9 & 2 & 1 & 18.00 & \\
\hline $\mathrm{C} 3$ & 8 & 1 & 0.66 & 5.28 & \\
\hline $\mathrm{C} 4$ & 7 & 2 & 1 & 14.00 & \\
\hline C5 & 8 & 2.5 & 1 & 20.00 & \\
\hline C6 & 7 & 1.5 & 0.66 & 6.93 & \\
\hline
\end{tabular}

Relative importance of the five major categories was found out on scale of 0 to 10 , so that sum total or rating shall be 10 , ten being highest influence level and one means the lowest on they were asked to weigh each category so that total sum count 1 . It is seen from Chart 1 that category D with weightage 3 is on top rank while A, B, C are weighing 2 and category $\mathrm{E}$ carries weightage of 1 . 


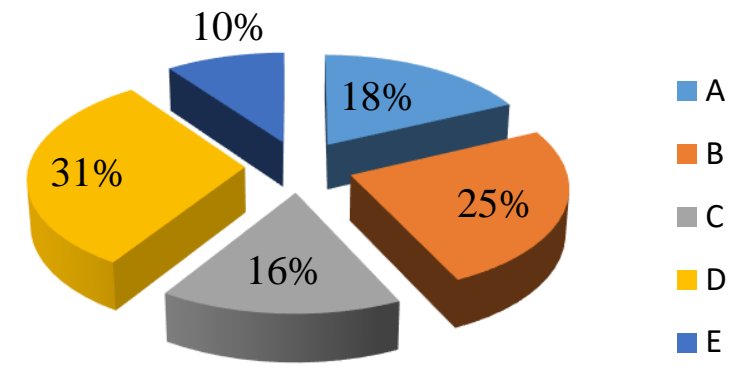

Chart-1: Weightages of major waste categories

Concrete waste index for each category and that CWI of project were derived as- Category index of category $(\mathrm{z})=$ Category weight $\mathrm{x}$ Category rating. They are tabulated in Table 5.

Table 5: Waste index of category

\begin{tabular}{|c|c|c|c|c|c|c|c|}
\hline $\begin{array}{l}\text { Fac } \\
\text { tor } \\
\text { Co } \\
\text { de }\end{array}$ & $\begin{array}{l}\text { Influe } \\
\text { nce } \\
\text { level } \\
\text { (a) }\end{array}$ & $\begin{array}{l}\text { Facto } \\
\mathrm{r} \\
\text { Weig } \\
\text { htage } \\
\text { (b) }\end{array}$ & $\begin{array}{l}\text { Aud } \\
\text { it } \\
\text { Sco } \\
\text { re } \\
\text { (c) }\end{array}$ & $\begin{array}{l}\text { Fact } \\
\text { or } \\
\text { rati } \\
\text { ng }\end{array}$ & $\begin{array}{l}\text { Cat } \\
\text { ego } \\
\text { ry } \\
\text { rati } \\
\text { ng }\end{array}$ & $\begin{array}{l}\text { Cat } \\
\text { ego } \\
\text { ry } \\
\text { wei } \\
\text { ght }\end{array}$ & $\begin{array}{l}\text { Wast } \\
\text { e } \\
\text { index } \\
\text { of } \\
\text { categ } \\
\text { ory }\end{array}$ \\
\hline $\mathrm{C}$ & $\begin{array}{l}(0 \text { to } \\
10)\end{array}$ & $\begin{array}{l}\text { (Total } \\
\text { sum } 1 \\
\text { withi } \\
\mathrm{n} \text { all } \\
\text { factor } \\
\mathrm{s})\end{array}$ & $\begin{array}{l}\text { (Lik } \\
\text { ert } \\
\text { scal } \\
\text { e) }\end{array}$ & $\begin{array}{l}\mathrm{d}= \\
\mathrm{a} * \mathrm{~b} \\
*_{\mathrm{c}}\end{array}$ & $\begin{array}{l}\mathrm{x}= \\
\Sigma \mathrm{d}\end{array}$ & $\begin{array}{l}\mathrm{y}= \\
\text { Tak } \\
\text { en } \\
\text { fro } \\
\mathrm{m} \\
\text { fig. } \\
1\end{array}$ & $\begin{array}{l}\mathrm{z}=\mathrm{x} \\
* \mathrm{y}\end{array}$ \\
\hline $\mathrm{C} 1$ & 7 & 1 & 0 & 0.00 & \multirow{6}{*}{$\begin{array}{l}64.2 \\
4\end{array}$} & \multirow{6}{*}{2} & \multirow{6}{*}{$\begin{array}{l}128.4 \\
4\end{array}$} \\
\hline $\mathrm{C} 2$ & 9 & 2 & 1 & $\begin{array}{l}18.0 \\
0\end{array}$ & & & \\
\hline C3 & 8 & 1 & 0.66 & 5.28 & & & \\
\hline $\mathrm{C} 4$ & 7 & 2 & 1 & $\begin{array}{l}14.0 \\
0\end{array}$ & & & \\
\hline C5 & 8 & 2.5 & 1 & $\begin{array}{l}20.0 \\
0\end{array}$ & & & \\
\hline C6 & 7 & 1.5 & 0.66 & 6.93 & & & \\
\hline
\end{tabular}

This gives an idea to the auditor about the relative influence level of each of the categories on generation of waste. In actual practice, a questionnaire survey can be done to get the actual results. More is the value of waste index greater are chances of generation of concrete waste, it means, more is the influence.

\subsection{Waste Index of Major Category}

All five categories were ranked and judged for their importance level to generate concrete waste in the project. Waste index for the respective category of waste was derived from the sample data. Concrete Waste Index (CWI) of project was calculated by summing up waste indices of each of the categories. CWI of project is the indicator of level of concrete waste. This index can be used to benchmark the concrete waste being generated on site. Waste index of category and CWI of these categories are presented in Table 6.

Table 6: CWI of project from WI of category

\begin{tabular}{|l|l|l|l|}
\hline $\begin{array}{l}\text { Category } \\
\text { Code }\end{array}$ & Category name & $\begin{array}{l}\text { WI of } \\
\text { category } \\
(\mathrm{z})\end{array}$ & $\begin{array}{l}\text { CWI of } \\
\text { project } \\
=\Sigma \mathrm{z}\end{array}$ \\
\hline A & $\begin{array}{l}\text { Design, Specifications } \\
\text { and Contract }\end{array}$ & 137 & \multirow{2}{*}{732} \\
\hline B & $\begin{array}{l}\text { Materials Machinery } \\
\text { and Equipment }\end{array}$ & 181 & \\
\hline C & Manpower and & 116 & \\
\hline D & $\begin{array}{l}\text { Project Management, } \\
\text { Planning and } \\
\text { Methodology (31\%) }\end{array}$ & 227 \\
\hline E & Other (Uncontrollable) & 71 & \\
\hline
\end{tabular}

Chart 2 is a graphical presentation of weightages of these categories.

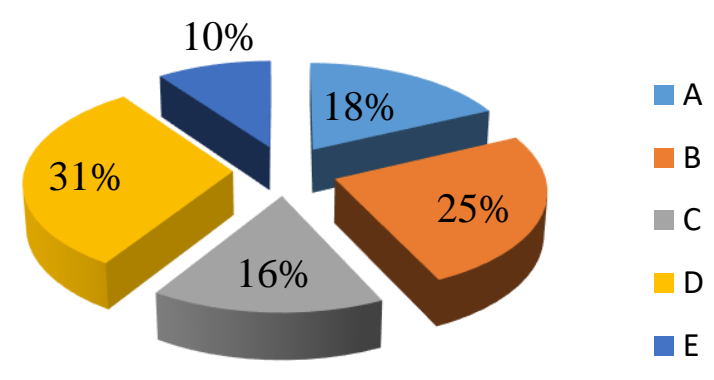

Chart-2: Weightages of major waste categories

\subsection{Standardization of Waste Parameters}

To nullify the effect of wrong database, absurd values were identified using mean and pre-defined limit of standard deviation (sd). Such data was filtered out and did not consider in further analysis. Table 7 represents the standard values of waste parameters being used further in development of mode. For standardization, standard deviation limit of 2.0 was considered for influence level, that of 0.5 for weightage of CWGF within the category and 0.33 for audits scores. This was done on the judgment of the researchers. Out of total 50, A2, E3, E4 factors were discarded in development of model from this process of standardization. Concrete waste audit sheet, thus obtained, is termed as 'Standardized Waste Audit Sheet'. 
Table 7: Standardized values of waste parameters

\begin{tabular}{|l|l|l|l|}
\hline & $\begin{array}{l}\text { Std. value } \\
\text { of influence } \\
\text { level }\end{array}$ & $\begin{array}{l}\text { Std. value } \\
\text { of } \\
\text { weightage } \\
\text { within } \\
\text { category }\end{array}$ & $\begin{array}{l}\text { Std. audit } \\
\text { score }\end{array}$ \\
\hline A1 & 6.15 & 1.24 & 1 \\
\hline A3 & 5.65 & 1.03 & 0.66 \\
\hline A4 & 7.00 & 1.68 & 0.66 \\
\hline A5 & 6.85 & 1.38 & 0.66 \\
\hline A6 & 6.30 & 1.16 & 0.66 \\
\hline A7 & 7.20 & 1.39 & 0.66 \\
\hline A8 & 6.55 & 0.84 & 0.66 \\
\hline A9 & 7.70 & 1.27 & 0.66 \\
\hline B1 & 6.00 & 0.54 & 0.66 \\
\hline B2 & 5.85 & 0.65 & 0.66 \\
\hline B3 & 6.11 & 0.65 & 0.66 \\
\hline B4 & 7.00 & 1.33 & 0.66 \\
\hline B5 & 6.05 & 0.56 & 0.66 \\
\hline B6 & 6.60 & 0.40 & 0.66 \\
\hline B7 & 8.40 & 0.63 & 0.66 \\
\hline B8 & 6.00 & 0.69 & 0.66 \\
\hline B9 & 8.30 & 1.26 & 0.66 \\
\hline B10 & 7.75 & 0.79 & 0.66 \\
\hline B11 & 8.05 & 0.53 & 0.66 \\
\hline B12 & 7.05 & 0.75 & 0.66 \\
\hline B13 & 5.45 & 0.58 & 0.66 \\
\hline B14 & 7.00 & 0.66 & 0.66 \\
\hline C1 & 6.55 & 1.48 & 0.66 \\
\hline C2 & 7.85 & 1.85 & 0.66 \\
\hline C3 & 7.45 & 1.31 & 0.66 \\
\hline C4 & 7.05 & 1.71 & 0.66 \\
\hline C5 & 7.60 & 2.04 & 0.66 \\
\hline C6 & 6.85 & 1.61 & 0.66 \\
\hline D1 & 6.60 & 1.33 & 0.66 \\
\hline D2 & 6.15 & 0.71 & 0.66 \\
\hline D3 & 7.15 & 0.55 & 0.66 \\
\hline D4 & 7.65 & 0.55 & 0.66 \\
\hline D5 & 5.85 & 0.43 & 0.66 \\
\hline D6 & 6.60 & 0.44 & 0.66 \\
\hline D8 & 7.50 & 0.53 & 0.66 \\
\hline
\end{tabular}

\begin{tabular}{|l|l|l|l|}
\hline D11 & 8.60 & 1.21 & 0.66 \\
\hline D12 & 5.95 & 0.54 & 0.66 \\
\hline D13 & 6.95 & 0.66 & 0.66 \\
\hline D14 & 7.50 & 0.78 & 0.66 \\
\hline D15 & 6.50 & 0.40 & 0.66 \\
\hline D16 & 8.75 & 0.46 & 0.66 \\
\hline E1 & 7.35 & 2.50 & 0.33 \\
\hline E2 & 7.35 & 3.75 & 0.66 \\
\hline E5 & 5.75 & 3.75 & 0.33 \\
\hline
\end{tabular}

\section{DATA ANALYSIS}

Using standardized values of waste parameters, standard values of Concrete waste index (CWI) of project were derived and are mentioned in table 8 . It was found out by adding waste indices of the categories which was derived as multiplication of sum of final factor weightage per category and importance level of category.

Table 8: CWI obtained from standard values of audit

\begin{tabular}{|c|c|c|c|c|}
\hline \multirow{3}{*}{$\begin{array}{l}\text { Factor } \\
\text { Category }\end{array}$} & \multicolumn{2}{|c|}{\begin{tabular}{ll|} 
& \multicolumn{2}{c}{ parameters } \\
Sum of
\end{tabular}} & & \multirow[b]{2}{*}{ CWI } \\
\hline & $\begin{array}{l}\text { Sum of } \\
\text { final } \\
\text { factor } \\
\text { weightage } \\
\text { per } \\
\text { category }\end{array}$ & $\begin{array}{l}\text { Importance } \\
\text { level of } \\
\text { category }\end{array}$ & \multirow[t]{2}{*}{$\begin{array}{l}\text { Waste } \\
\text { Index } \\
\text { for the } \\
\text { category }\end{array}$} & \\
\hline & $0 \leq 100$ & $0 \leq 10$ & & $\begin{array}{l}\text { (out } \\
\text { of } \\
1000)\end{array}$ \\
\hline $\mathrm{A}$ & 38.01 & 2 & 76 & \multirow{5}{*}{378} \\
\hline B & 39.49 & 2 & 79 & \\
\hline $\mathrm{C}$ & 40.99 & 2 & 82 & \\
\hline $\mathrm{D}$ & 40.26 & 3 & 121 & \\
\hline$E$ & 20.13 & 1 & 20 & \\
\hline
\end{tabular}

To find the more accurate value of the CWI, sample was revised. Auditors whose CWI value was found close to 378 were considered valid. CWI range in between 244 and 481 was decided by researcher to revise the sample size. Revised values after this iteration are mentioned in Table 9.

Nine auditors highlighted in table - 1, 4, 12, 13, 14, 15, 16, 24, 26 were found to fit into this limit and are declared as expert auditors. Repetition of the earlier described analysis process was carried out to get revised values of CWI. Table 10 represents final CWI value after 3 iterations.

Table 9: CWI using standardized parameters- regression 1

\begin{tabular}{|l|l|l|l|}
\hline $\begin{array}{l}\text { Auditor } \\
\text { no. }\end{array}$ & CWI & $\begin{array}{l}\text { Auditor } \\
\text { no. }\end{array}$ & CWI \\
\hline 1 & 403 & 16 & 481 \\
\hline 2 & 532 & 17 & 483 \\
\hline 3 & 535 & 18 & 484 \\
\hline 4 & 244 & 19 & 518 \\
\hline 6 & 516 & 20 & 549 \\
\hline
\end{tabular}




\begin{tabular}{|l|l|l|l|}
\hline 9 & 524 & 21 & 548 \\
\hline 10 & 490 & 22 & 539 \\
\hline 12 & 366 & 23 & 505 \\
\hline 13 & 367 & 24 & 439 \\
\hline 14 & 415 & 25 & 543 \\
\hline 15 & 263 & 26 & 367 \\
\hline
\end{tabular}

Table 10: CWI obtained using redefined standard values of audit parameters.

\begin{tabular}{|l|l|l|l|l|}
\hline \multirow{4}{*}{$\begin{array}{l}\text { Factor } \\
\text { Category }\end{array}$} & $\begin{array}{l}\text { Sum of } \\
\text { final } \\
\text { factor } \\
\text { weightage } \\
\text { per } \\
\text { category }\end{array}$ & $\begin{array}{l}\text { Importa } \\
\text { nce } \\
\text { level of } \\
\text { categor } \\
\text { y }\end{array}$ & $\begin{array}{l}\text { Waste } \\
\text { Index } \\
\text { for the } \\
\text { category }\end{array}$ & $\begin{array}{l}\text { Waste } \\
\text { Index of } \\
\text { site }\end{array}$ \\
\cline { 2 - 4 } & $0 \leq 100$ & $0 \leq 10$ & $\begin{array}{l}\text { (out of } \\
1000)\end{array}$ \\
\hline A & 47.04 & 2 & 94 & \multirow{2}{*}{454} \\
\hline B & 45.92 & 2 & 92 & \\
\hline D & 47.89 & 2 & 96 & 141 \\
\hline E & 46.98 & 3 & 31 & \\
\hline
\end{tabular}

The adaptability of CWA tool on site to find \% concrete waste was proven by establishing the relationship between CWI calculated using and actual \% on site concrete waste.

Auditors were asked to find the on-site concrete waste for the sites under consideration by using the traditional tool available in their company. Most of the auditors found onsite concrete waste from the consumption of cement bags and its estimated quantity. This value was presumed to be correct and used in the analysis by the researcher. The sample data was then created consisting of on-site \% concrete waste and corresponding CWI obtained using CWA tool. Table 11 shows the comparison of rating of these auditors by using audit tool and concrete waste (\% of the estimated quantity of concreting- $\mathrm{Q}_{\mathrm{e}}$ ).

Regression analysis was carried out to define the relationship between these two parameters. SPSS Statistics 12 software was used for this analysis. In the first trial, with the given sample data of 20 size, only cubic equations found to give satisfactory result. For estimating best fit of curve Chi-square test was performed between the actual values and values obtained from analysis.

Waste Audit Score $=(1240.71 * x)-\left(369.765 * x^{2}\right)+\left(36.6 * x^{3}\right)-$ 865.45 ....(1)

Wherein, $x=\%$ concrete waste (observed value)

Table 11: Concrete waste $\left(\%\right.$ of $\left.\mathrm{Q}_{\mathrm{e}}\right) \mathrm{V} / \mathrm{S}$ CWI

\begin{tabular}{|c|c|c|c|c|c|}
\hline $\begin{array}{l}\text { Audito } \\
\mathrm{r}\end{array}$ & $\begin{array}{l}\text { CWI } \\
\text { using } \\
\text { wast } \\
\text { e } \\
\text { audit } \\
\text { tool }\end{array}$ & $\begin{array}{l}\text { Concret } \\
\text { e waste } \\
(\% \text { of } \\
\left.\mathrm{Q}_{\mathrm{e}}\right)\end{array}$ & $\begin{array}{l}\text { Audito } \\
\mathrm{r}\end{array}$ & $\begin{array}{l}\text { CWI } \\
\text { using } \\
\text { wast } \\
\text { e } \\
\text { audit } \\
\text { tool }\end{array}$ & $\begin{array}{l}\text { Concret } \\
\text { e waste } \\
(\% \text { of } \\
\left.\mathrm{Q}_{\mathrm{e}}\right)\end{array}$ \\
\hline 1 & 403 & 1.8 & 17 & 483 & 2.4 \\
\hline
\end{tabular}

\begin{tabular}{|c|c|c|c|c|c|}
\hline 2 & 532 & 4 & 18 & 484 & 2.5 \\
\hline 3 & 535 & 4.1 & 19 & 518 & 3.5 \\
\hline 6 & 516 & 3.1 & 20 & 549 & 4.5 \\
\hline 9 & 524 & 3.6 & 21 & 548 & 4.4 \\
\hline 10 & 490 & 2.75 & 22 & 539 & 4.1 \\
\hline 12 & 366 & 1.6 & 23 & 505 & 3 \\
\hline 13 & 367 & 1.65 & 24 & 439 & 2 \\
\hline 14 & 415 & 2 & 25 & 543 & 4.2 \\
\hline 16 & 481 & 2.2 & 26 & 367 & 1.7 \\
\hline
\end{tabular}

The result showed the greater level of variance than expected. In the next revision, auditors whose CWI was found to fall within the limit $454 \pm 50$ only was considered to form the revised sample. A cubic curve, as shown in Figure 1 was found to fit for the given relationship. The curve obtained found to be closely fit to describe the desired relationship.

$$
\mathrm{CWI}=6.294-9.02 * 10^{\wedge}-5 * \mathrm{Y}^{2}+1.5331 * 10^{\wedge}-7 * \mathrm{Y}^{3}
$$

Wherein, $\mathrm{Y}=$ Concrete waste audit score obtained from audit questionnaire.

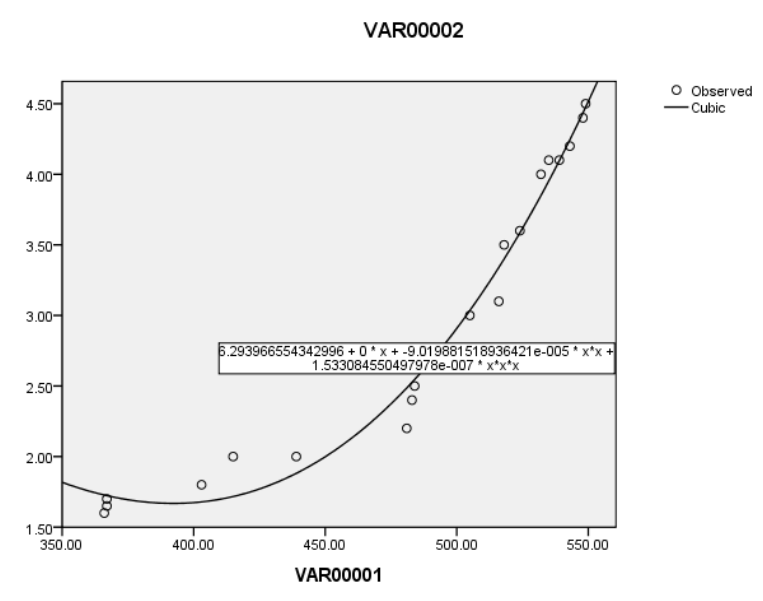

Fig 1: Cubic curve derived from regression analysis

Using equation (2), CWI values were derived. Chi-square test was used to measure the goodness of fit which was the sum of differences between observed and expected outcome frequencies (that is, counts of observations), each squared and divided by the expectation which is given in eq. (3). Results are tabulated in the Table 12.

$$
\chi^{2}=\sum^{\mathrm{n}} \mathrm{x} \frac{(\mathrm{Oi}-\mathrm{Ei}) 2}{\mathrm{Ei}}
$$

Where, $O_{i}=$ an observed frequency (i.e. count); $E_{i}=$ an expected (theoretical) frequency. 
Table 12: Chi-square test results with revised equation

\begin{tabular}{|l|l|l|l|}
\hline $\begin{array}{l}\text { Auditor } \\
\text { No. }\end{array}$ & $\begin{array}{l}\text { \% } \\
\text { Concrete } \\
\text { waste } \\
\text { observed }\end{array}$ & $\begin{array}{l}\text { Expected \% } \\
\text { (Tool based } \\
\text { outcome) }\end{array}$ & $\begin{array}{l}\text { Chi-square } \\
\text { value }\end{array}$ \\
\hline 12 & 1.6 & 1.73 & 0.009430 \\
\hline 13 & 1.65 & 1.72 & 0.003118 \\
\hline 26 & 1.7 & 1.72 & 0.000315 \\
\hline 1 & 1.8 & 1.68 & 0.008724 \\
\hline 14 & 2 & 1.72 & 0.046685 \\
\hline 24 & 2 & 1.88 & 0.007491 \\
\hline 16 & 2.2 & 2.49 & 0.032965 \\
\hline 17 & 2.4 & 2.53 & 0.006293 \\
\hline 18 & 2.5 & 2.55 & 0.000845 \\
\hline 10 & 2.75 & 2.67 & 0.002175 \\
\hline 23 & 3 & 3.04 & 0.000408 \\
\hline 6 & 3.1 & 3.34 & 0.017340 \\
\hline 19 & 3.5 & 3.40 & 0.002940 \\
\hline 9 & 3.6 & 3.59 & 0.000061 \\
\hline 2 & 4 & 3.85 & 0.005929 \\
\hline 3 & 4.1 & 3.95 & 0.005472 \\
\hline 22 & 4.1 & 4.10 & 0.000004 \\
\hline 25 & 4.2 & 4.24 & 0.000456 \\
\hline 21 & 4.4 & 4.44 & 0.000297 \\
\hline 20 & 4.5 & 4.48 & 0.000132 \\
\hline$\Sigma$ Chi-Square values: & & 0.151079 \\
\hline $\begin{array}{l}\text { Tabulated } \\
\text { significance: }\end{array}$ & folue & $1 \%$ level & \\
\hline & & & 7.633 \\
\hline
\end{tabular}

It was observed that tool-based outcomes match relatively well with the values obtained from manual evaluation of the projects. As the obtained value was much less than the tabulated value for $1 \%$ level of significance, the equation derived holds good to describe the desired relationship between CWI and \% concrete waste on site. As seen in Table 10, only in three cases - 6, 14 and 16, there found to have mismatch. The main reason for this discrepancy was that the project evaluator had an overly optimistic judgment of the subject project.

\subsection{Concrete Waste Index of Category}

By using the standardized values of the audit parameters, following values of CWI values for respective category of CWIF were derived which were used in the standard concrete waste audit tool. Category D - "Project Management, Planning and Methodology" was found to have $32 \%$ of the contribution in deciding the CWI of a project site. It is shown in the Table 13.

Table 13: Weightage of factor category

\begin{tabular}{|l|l|l|l|}
\hline Category & Category & Waste index & $\begin{array}{l}\text { Weightage } \\
\text { of category } \\
\text { in CWI }\end{array}$ \\
\hline A & $\begin{array}{l}\text { Design, } \\
\text { Specifications } \\
\text { and Contract }\end{array}$ & 76 & $20 \%$ \\
\hline B & $\begin{array}{l}\text { Materials, } \\
\text { Machinery and } \\
\text { Equipment }\end{array}$ & 79 & $21 \%$ \\
\hline
\end{tabular}

\begin{tabular}{|l|l|l|l|}
\hline C & Man Power & 82 & $22 \%$ \\
\hline D & $\begin{array}{l}\text { Project } \\
\text { Management, } \\
\text { Planning and } \\
\text { Methodology }\end{array}$ & 121 & $32 \%$ \\
\hline E & $\begin{array}{l}\text { Other } \\
\text { (Uncontrollable) }\end{array}$ & 20 & $5 \%$ \\
\hline
\end{tabular}

\subsection{Classification of Audit Score}

In order to guide the practitioners to exercise the concrete waste audit practices, the researchers classified the CWI scores into four levels, i.e., excellent, good, fair, and poor. It is tabulated in Table 14.

Table 14: Guideline to describe the concrete waste control level

\begin{tabular}{|l|l|l|}
\hline $\begin{array}{l}\text { CW Audit score } \\
\text { level }\end{array}$ & $\begin{array}{l}\text { Level of } \\
\text { control }\end{array}$ & $\begin{array}{l}\text { \% Concrete waste } \\
\text { on site }\end{array}$ \\
\hline$<450$ & Excellent & $<2 \%$ \\
\hline 451 to 505 & Good & 2 to $3 \%$ \\
\hline 506 to 537 & Fair & 3.1 to $4.0 \%$ \\
\hline$>537$ & Poor & $>4.0 \%$ \\
\hline
\end{tabular}

\subsection{Design of Concrete Waste Audit tool}

Equation 4 was derived from the regression analysis result produced using SPSS software.

$$
\mathrm{CWI}=\left\{\sum_{k=1}^{n}\left[\sum_{\mathrm{i}=1}^{5}\left(\sum_{\mathrm{j}=1}^{\ell} \mathrm{AS}_{\mathrm{ijk}} \times \mathrm{CW}_{\mathrm{ijk}} \times \mathrm{IL}_{\mathrm{ijk}}\right) \times \mathrm{ILCW}_{\mathrm{ik}}\right]\right\}
$$

Wherein,

$\mathrm{AS}_{\mathrm{ij}}=$ Audit score of $\mathrm{k}^{\text {th }}$ auditor for $\mathrm{j}^{\text {th }}$ factor in $\mathrm{i}^{\text {th }}$ category $\left(0<\mathrm{AS}_{\mathrm{ijk}} \leq 1\right)$ for such ' $\ell$ ' no. of factors within ' $\mathrm{i}$ ' category; $\mathrm{CW}_{\mathrm{ij}}=$ Category weightage of $\mathrm{k}^{\text {th }}$ auditor for $\mathrm{j}^{\text {th }}$ factor in $\mathrm{i}^{\text {th }}$ category

$\left(0<\mathrm{CW}_{\mathrm{ijk}} \leq 10\right)$ for such ' $\ell$ ' no. of factors within ' $\mathrm{i}$ ' category;

$\mathrm{IL}_{\mathrm{ij}} \quad=$ Influence level of $\mathrm{k}^{\text {th }}$ auditor for $\mathrm{j}^{\text {th }}$ factor in $\mathrm{i}^{\text {th }}$ category

$\left(0<\mathrm{AS}_{\mathrm{ijk}} \leq 10\right)$ for such ' $\ell$ ' no. of factors within ' $\mathrm{i}$ ' category;

$\mathrm{ILCW}_{\mathrm{i}}=$ Weight of Importance level of $\mathrm{i}^{\text {th }}$ category $\left(0<\mathrm{ILCW}_{\mathrm{i}} \leq 5\right)$

$\mathrm{n}=$ total number of auditors under consideration

\section{OBSERVATIONS AND FINDINGS}

Following study observations and findings are derived from this study.

Out of total 50 CWIFs, 3 factors viz. A2, E3 and E5 were rejected from study to design of the audit tool. These were A2) excess safety margin, E3) Accidents and mishaps and E5) Rainfall, breakdown in law and order, change in rule etc. requiring rework. Out of five major factor categories, category D)- Project Management, Planning \& Methodology 
was found to have highest value of waste index with about $31 \%$ weightage amongst five and category B) - Materials, Machinery and Equipment with 25\%. From the first iteration, CWI obtained was 378 which was revised to 454 in further iteration after excluding irrelevant values. SPSS Statistical 12 software was used and found useful to establish the relationship between calculated CWI and observed $\%$ of concrete waste. Cubic equation was found to give more realistic results. \% waste of concrete was derived using equation

$=6.294-9.02 * 10^{\wedge}-5 * Y^{2}+1.5331 * 10^{\wedge}-7 * Y^{3}$

Model was designed to find concrete waste index which was represented as-

$$
\mathrm{CWI}=\left\{\sum_{k=1}^{n}\left[\sum_{\mathrm{i}=1 \mathrm{j}=1}^{5}\left(\sum_{\mathrm{j}}^{\ell} \mathrm{AS}_{\mathrm{ijk}} \times \mathrm{FW}_{\mathrm{ijk}} \times \mathrm{IL}_{\mathrm{ijk}}\right) \times \mathrm{ILCW}_{\mathrm{ik}}\right]\right.
$$

Validation of tool was carried out for the data of 10 various projects. Results are testing using Chi-Square test. Tool based outcome was found to be 1.900 which was much less than the tabulated value at $5 \%$ level of significance = 16.919 .

\section{CONCLUSIONS AND PRACTICAL APPLICATIONS}

In this study, the audit tool designed and tested seems to provide a reasonably robust and easy to use tool to audit concrete waste generated from housing projects in India. Waste is a non value adding activity that adds to the losses. Reducing concrete waste contributes to environmental sustainability by saving excess use of natural materials like rock and sand. Material wastage is not always avoidable and concrete waste is vital account for about 1 to $15 \%$ of material quantity.

Indian real estate industry is facing challenges to measure waste quantities on site and hence practitioners find it difficult to design waste audit methodology and establish control system to manage it.

This study has twofold approach. One is indemnification of 47 various factors influencing concrete waste which were grouped in five major categories. These categories were prioritized in this study. This study guides practitioners in reducing waste and saving on losses by diverting focus on more important parameters. The other is the development of an audit methodology for assessing concrete waste. The reliability of data being collected is assumed to be satisfactory. It is recommended to carry a more rigorous data collection and in-depth validation test with larger and statistically significant data to increase the reliability of the model presented in this study. Audit tool proved to be a practical tool for use on Indian construction site. 51 audited sites in this study and10 case used for validation of tool provide a snapshot sample of waste production in real estate industry in Maharashtra, India. The result provides the industry with a set of standardized parameters of concrete waste generation factors viz. influence level, weightages of factor within category, audit score and importance level of each category.

\section{ACKNOWLEDGEMENT}

The writers like to thank all the industry experts, practitioners and individuals who willing participated in the survey carried out. Efforts of all respondents and reviewers of Indian real estate industry are well acknowledged.

\section{REFERENCES}

[1]. Koskela, L. (1992). "Application of the New Production Philosophy to Constriction."CIFE, Technical report No. 72, Stanford, USA.

[2]. Bossink B. A. G. and Brouwers H. J. H. (1996). "Construction waste: Quantification and source evaluation," J. Constr. Engrg. And Mgmt., ASCE, March, 55-59.

[3]. Teo, S.P., Abdelnaser, O. and Abdul, H. K. (2009), “ Material wastage in Malaysian construction industry", International conference on Economic and Administration, Faculty of Administration University of Bucharest Romania, pp257-264.

[4]. Ruben Ndihokubwayo and Theo Haupt (2009). "Variation orders on construction projects: Value adding or waste?" International journal of Construction Project Management, Vol. 1, issue 2, pp. 1-1

[5]. Formoso,C.T., Soibelman L., Cesare C. D., Isatto E. L. (2002). "Material Waste In Building Industry: Main Causes And Prevention," J. Constr. Engrg. And Mgmt., ASCE, July/August, 316-325.

[6]. Josephson, P. E. and Saukkoriipi , L. (2007): A report on "Waste in Construction Projects: Call for a new approach,”, ISBN 978-91-976181-7-5.

[7]. Kosela, L. (1992). “Application Of The New Production Philosophy To Construction," Tech. Rep. No. 72, CIFE, Stanford, Calif.

[8]. Sawant P.H. and Alone S. V. and (2012), "Construction Waste: Source Identification, Quantification and Its Management in Housing Projects" Proceedings of the International Conference on Sustainable Built Environment, ICSBE 2012, 14-16 Dec. 2012, pp 90. ISBN 9789555 495806.

[9]. Ramaswamy, K. P. and Kalidindi, S. N. (2009). "Waste in Indian Building Construction Projects,".

[10]. Poon C.S., Yu A.T.W. and Jaillon L. (2004). "Reducing Building Waste At Construction Sites In Hong Kong," Construction Management and Economics (June 2004), 22, pp. 461-470.

[11]. Shen L. Y., Tan V.W.Y., Tam C.M., Ho S. (1994). "Material Wastage In Construction Activities, A Hong Kong Survey," 2004, pp. 125-131.

[12]. Vaid, K.N., and Tanna, A. (1994). "Wastage Control Of Building Materials In Construction Of Mass Housing Projects," NICMAR publication.

[13]. Pinto, T.P., Agopayan, V. (1994). Construction wastes as raw material for low-cost construction products. Sustainable Construction (Proc. 1st conf. of CIB TG 16), 
C.J. Kibert, ed., Ctr. For Constr. and Envir., Gainesville, Fla., pp. 335-342

[14]. Skoyles, E.R., and Skoyles, J.R. (1987). Waste prevention on site. Mitchell Publishing Company Limited. London.

\section{BIOGRAPHIES}

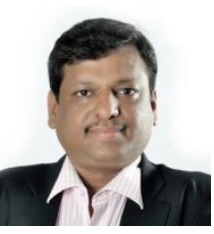

Sameersinh Alone is post graduate in construction management and is into this research since last 5 years. $\mathrm{He}$ is a research scholar at SPCOE, Mumbai and working at Infini Institute, Pune.

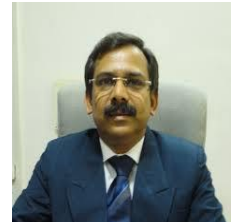

Dr. P H Sawant is associated with Sardar Patel College of Engineering and has completed doctoral research in Water Resources engineering from IISc Bangalore and MTech from IIT, Mumbai 